\title{
Water Safety Plan as a Tool for Improved Quality of Municipal Drinking Water in Nigeria
}

\author{
Emma E. Ezenwaji ${ }^{*}$, Philip 0. Phil-Eze ${ }^{2}$ \\ ${ }^{1}$ Department of Geography and Meteorology, Nnamdi Azikiwe University, Awka, Nigeria \\ ${ }^{2}$ Department of Geography, University of Nigeria, Nsukka, Nigeria \\ Email: ${ }^{*}$ emmaezenwaji@gmail.com
}

Received 16 April 2014; revised 12 May 2014; accepted 7 June 2014

Copyright @ 2014 by authors and Scientific Research Publishing Inc.

This work is licensed under the Creative Commons Attribution International License (CC BY). http://creativecommons.org/licenses/by/4.0/

c) (i) Open Access

\section{Abstract}

Nigerian standard for drinking water quality 2007 emphasized that all water service providers including State Water Agencies and Community Water Committees shall develop a water safety plan. This ensures the minimization of contamination of water supply from source, reduction or removal of contamination through treatment processes and prevention of contamination during storage, distribution and handling of drinking water. The aim of this study is to explain the meaning of water safety plan and highlight its importance including the ways it can be employed to achieve enhanced piped distribution of drinking water of good quality. The assessment of its level of development in Nigeria, the extent it can be employed to improve the present low health status of Nigerian urban populace, as well as its implication to general urban development in the country were discussed. It is concluded that an articulate and urgent water safety plan are necessary for the sustainability of urban water supply.

\section{Keywords}

Agencies, Contamination, Safety, Service, Source

\section{Introduction}

The Nigerian standard for drinking water quality 2007 emphasized that all water providers including the State Water Agencies (SWAs) and Community Water Committees (CWCs) shall develop a water safety plan. The intension is to ensure that pollution of water supply from sources is minimized through treatment processes and

*Corresponding author.

How to cite this paper: Ezenwaji, E.E. and Phil-Eze, P.O. (2014) Water Safety Plan as a Tool for Improved Quality of Municipal Drinking Water in Nigeria. Journal of Environmental Protection, 5, 997-1002.

http://dx.doi.org/10.4236/jep.2014.511100 
prevention of contamination during storage, distribution and handling of drinking water. According to Ezemonye [1] in Nigeria, water supply for public consumption and use is the constitutional responsibility of the three tiers of government (i.e. The Federal, State and Local Governments) who unfortunately have not done much to improve the quality of drinking water. The water supply inadequacies which majorly gave rise to this problem as a result of intermittent supply stem from the fact that most of the Water Works established before 1920 have undergone little maintenance and as a result are dysfunctional. The dysfunctional Water Works have so decreased supply that many of them only now produce and distribute about $10 \%-15 \%$ of the entire demand. Even with the external support to State Governments over the years, full capacity utilization of water supply projects has remained unachieved in Nigerian urban centres. Thus many more people have been using the same level of water facilities for many years, meaning that the urban population has been on the increase without corresponding increase in water supply facilities. Thus obtaining water in some Nigerian urban areas has become an issue of quality as even the small available quantities are polluted considerably.

Quite surprising is that water obtained from some municipal water authorities through piped water supply system has become so poor in quality that its utilization for any meaningful purpose is highly reduced. Unsuspecting consumers who usually place much confidence in municipal supply have found to their dismay that they are at much risk of contacting waterborne diseases by consuming water from such source, the same situation they found themselves when they were consuming water from supplemental sources such as shallow wells, water vendors, streams etc. Presently, many of the water supply agencies especially the State Water Authorities do not place any regard to water quality monitoring, the absence of which has been the major reason for their delivery of poor quality water to consumers. The continuation of this problem despite repeated calls for it to be readdressed is of great concern. The aim of this study is therefore to examine the concept of water safety plan and the extent of its application to Nigerian urban areas.

\section{The Concept of Water Safety Plan}

Water safety plan according to Bartram, et al. [2] is the prevention of contamination of water from the source to the point of consumption and gives consumers greater involvement and control over maintaining water quality. Ensuring delivery of safe water has relied on testing water quality at the point of entry to the distribution system, the point of delivery or at the point of use. WEDC [3] noted that in 2004 the World Health Organization (WHO) launched the third edition of the Guidelines for Drinking Water Quality (GDWQ) with a fourth edition published in 2011. These global guidelines are the principal document in water quality and they outlined a fundamental change in the approach to drinking water quality control. The GDWQ promote the use of water safety plans (WSPs) which emphasise thorough risk assessment leading to effective risk management, and use of simple indicators to monitor, process and control water quality with periodic verification through the auditing of microbial indicators. WSPs are important for any water supply scheme as they are the only plan that would give direction to water quality monitoring in the entire supply chain.

WSPs is developed based on five stages which are 1) Preparation; 2) System assessment; 3) Operational monitoring; 4) Management and communication; 5) Feedback and improvement. Each of these stages handles specific area of the plan, while the co-ordination of all of them results in a good plan. Figure 1 is a schematic presentation of the development and implementation of WSP.

The plan shows that lack of proper attention of the operator in any of the stages may likely result in the collapse of the plan. Despite its limitations which include 1) that the plans are only as good as the information available and how effective they are planned and implemented and 2) that it addresses issues of water quality but cannot achieve other issues such as water quantity or deciding between different water use priorities. The absence of WSPs in any water utility usually leads to the supply of water of doubtful quality.

Of particular importance in the plan development is the risk management after a hazardous event has been established. Hazardous event is the possible contaminations or interruption of a water supply system. The risk associated with each event is usually assessed to determine both the frequency and the severity of the hazard. Smith and Reed [4] were of the view that once the cause of a hazard (contamination) event is identified using sanitary inspection methods, controlling them can then be established by the use of monitored surrogate parameters such as chlorine residuals, $\mathrm{pH}$, conductivity corrective or remedial actions when the parameter is exceeded. The following information need to form an indispensable part of any WSP:

1) Hazard event

2) Assessed risk 


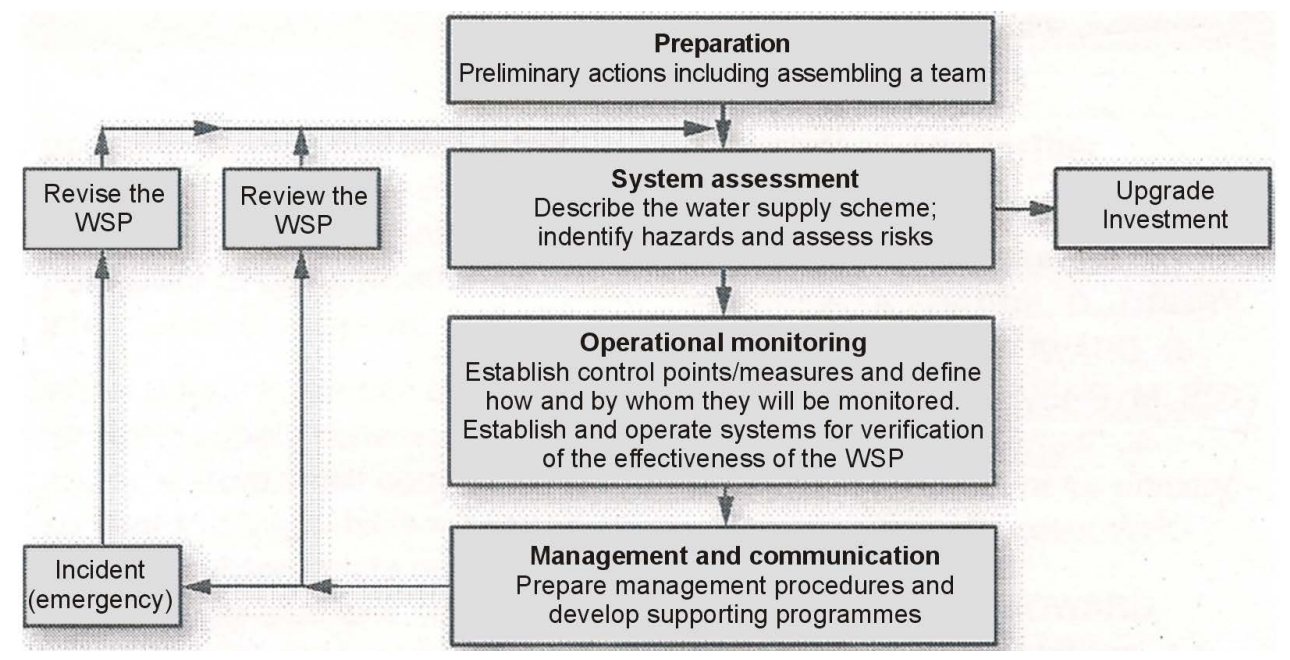

Figure 1. Development and implementation of a water safety plan after smith and reed (2013).

3) Control measures

4) Critical limits

5) Monitoring (method, frequency and body to monitor hazards and associated risk)

6) Corrective action

7) Verification (test of effectiveness of WSP).

Example of the matrix of water safety plan is shown in Table 1.

These required information were examined in six urban areas in Nigeria with functional public water supply to determine their water quality status, and extent of its application in the Nigerian urban centres.

\section{Methods}

In order to objectively appraise water safety plan in Nigeria, an adaptation of likert 5-point continuum weighting scale was applied to six selected urban centres where we had earlier carried out research investigation with the aid of 30 questionnaire which were administered on 6SWA officers in each State. The basis for the selection of the study urban area was the presence and functioning of public water supply. As a result of this, six urban areas were selected from different parts of the country as follows (Table 2).

The weighting scale (Table 3 ) ranged from urban areas with poor safety plan (scale of 1) to urban areas with effective water safety plan (scale of 5) with regard to seven (7) water safety plan information indices to be assessed.

The result obtained by employing the weighting scale is shown in Table 4 which indicates that only two urban centres are presently effectively in carrying out water safety plan. They are those that scored a total of above $60 \%$ or $21 \%$ absolute value in the evaluation exercise.

The two urban areas that perform well are Sokoto $26 \%$ or $74 \%$ and Zaria with $25 \%$ or $71 \%$. To statistically determine the significance of these differences in the performance of information from selected towns, Kruskal Wallis Test was carried out with the aid of Statistical Package for Social Sciences (SPSS) version 20.

Kruskal Wallis Test is the non-parametric analogue to one way analysis of variance. It is used to test whether a difference in the means of more than two independent samples is statistically significant. The general formula for computing Kruskal Wallis with K samples is given by Hinkle et al. [5] as

$$
\mathrm{H}=\frac{12}{N(N-1)} \sum_{J=i}^{K} \frac{R j^{2}}{n j}-3(N-1)
$$

where

$N=\sum_{J=i}^{K} n j$ is the total number of observations

$n j$ is the number of observations in $j$ th sample

$R j$ is the sum of the ranks in the $j$ th samples. 
Table 1. Example of a water safety matrix.

\begin{tabular}{|c|c|c|c|c|c|c|c|c|c|}
\hline \multirow{2}{*}{ Hazard Event } & \multirow{2}{*}{ Cause } & \multirow{2}{*}{ Risk } & \multirow{2}{*}{ Control } & \multicolumn{2}{|c|}{ Critical Limits } & \multicolumn{3}{|c|}{ Monitoring } & \multirow{2}{*}{$\begin{array}{c}\text { Corrective } \\
\text { Action }\end{array}$} \\
\hline & & & & Target & Action & What & When & Who & \\
\hline $\begin{array}{l}\text { Microbal } \\
\text { contamination } \\
\text { of a service } \\
\text { reservoir from } \\
\text { birds }\end{array}$ & $\begin{array}{c}\text { Birds } \\
\text { faeces enter } \\
\text { through } \\
\text { open } \\
\text { inspection } \\
\text { hatches }\end{array}$ & $\begin{array}{c}\text { Moderate } \\
\text { catastrophic }\end{array}$ & $\begin{array}{l}\text { Inspection } \\
\text { covers } \\
\text { remains in } \\
\text { place }\end{array}$ & $\begin{array}{l}\text { Inspection } \\
\text { covers } \\
\text { locked in } \\
\text { place }\end{array}$ & $\begin{array}{l}\text { Inspection } \\
\text { covers not } \\
\text { in place or } \\
\text { unlocked }\end{array}$ & $\begin{array}{c}\text { Sanitary } \\
\text { inspection } \\
\text { and } \\
\text { chlorine } \\
\text { level } \\
\text { assessment }\end{array}$ & Daily & $\begin{array}{l}\text { Operati } \\
\text { ng staff }\end{array}$ & $\begin{array}{c}\text { Replace } \\
\text { inspection } \\
\text { cover and } \\
\text { check } \\
\text { chlorine } \\
\text { residual }\end{array}$ \\
\hline
\end{tabular}

Table 2. Selected urban areas in Nigeria.

\begin{tabular}{ccc}
\hline S/N & State & Selected Urban Area \\
\hline 1 & Taraba & Jalingo \\
2 & Sokoto & Sokoto \\
3 & Kaduna & Zaria \\
4 & Imo & Owerri \\
5 & Oyo & Ibadan \\
6 & Rivers & Port Harcourt \\
\hline
\end{tabular}

Table 3. Weighting of water safety plan information indices for Nigeria.

\begin{tabular}{cccccc}
\hline Weighting Scale & $\mathbf{5}$ & $\mathbf{4}$ & $\mathbf{3}$ & $\mathbf{2}$ & $\mathbf{1}$ \\
\hline Information description & Very effective & Effective & Fair & Poor & Very poor \\
\hline
\end{tabular}

Table 4. Water safety plan effectiveness interaction matrix for Nigeria.

\begin{tabular}{|c|c|c|c|c|c|c|c|}
\hline \multirow{2}{*}{$\mathrm{S} / \mathrm{N}$} & \multirow{2}{*}{$\begin{array}{l}\text { WSP Information } \\
\text { Indices }\end{array}$} & \multicolumn{6}{|c|}{ Urban Areas } \\
\hline & & Jalingo & Sokoto & Zaria & Owerri & Ibadan & Port Harcourt \\
\hline 1 & Hazard Event & 4 & 5 & 5 & 2 & 3 & 2 \\
\hline 2 & Assessed Risk & 2 & 5 & 4 & 2 & 2 & 2 \\
\hline 3 & Control Measures & 2 & 4 & 5 & 1 & 2 & 2 \\
\hline 4 & Critical limits & 1 & 4 & 5 & 2 & 2 & 1 \\
\hline 5 & Monitoring & 3 & 4 & 4 & 1 & 3 & 1 \\
\hline 6 & Corrective action & 2 & 2 & 1 & 1 & 3 & 2 \\
\hline \multirow[t]{3}{*}{7} & Verification & 1 & 2 & 1 & 1 & 1 & 2 \\
\hline & Total & 15 & 26 & 25 & 10 & 16 & 12 \\
\hline & Percentage & $43 \%$ & $74 \%$ & $71 \%$ & $28 \%$ & $46 \%$ & $34 \%$ \\
\hline
\end{tabular}

\section{Result and Discussion}

The result of the Kruskal Wallis Test is presented in Table 5.

$$
\begin{array}{lll}
H=6.28 & \text { Df }=5 & \mathrm{p}=0.036 \\
\mathrm{H}=6.72 & \mathrm{Df}=5 & \mathrm{p}=0.024 \text { (adjusted for ties) }
\end{array}
$$

The calculated p-value of 0.024 is less than the critical value of 0.05 , implying that there is enough evidence to establish that there is a significant difference in the observations among the urban communities in the six geographical zone. The above shows that the urban areas considered differed significantly from one another.

From Table 5 it could be seen that it is only in Sokoto and Zaria urban areas that the model seems to be working well. Incidentally these two urban areas are found in the northern parts of the country, while two others from the south, Owerri (28\%) and Port Harcourt (34\%) exhibit very poor values showing that WSP is barely practiced in the two southern urban areas. In the areas where the plan works well, we found during the field 
Table 5. Result of Kruskal Wallis statistics.

\begin{tabular}{|c|c|c|c|c|}
\hline Factors & $\mathbf{N}$ & Median & Av Rank & $\mathbf{Z}$ \\
\hline 1 & 7 & 3.00 & 74.1 & -1.12 \\
\hline 2 & 7 & 6.00 & 97.2 & 0.04 \\
\hline 3 & 7 & 8.00 & 98.3 & 1.19 \\
\hline 4 & 7 & 2.00 & 64.6 & -1.32 \\
\hline 5 & 7 & 3.00 & 77.4 & 0.16 \\
\hline 6 & 7 & 2.00 & 69.6 & 0.40 \\
\hline Overall & 42 & & 80.2 & \\
\hline
\end{tabular}

work that the piped distribution of drinking water offer good quality water to consumers unlike the complaints we received from consumers in the urban areas where the plan hardly works, that their piped water have odour and at times impurities.

Absence or poor execution of WSP has dire consequences for public health as there is poor or no identification or control points of hazard events as well as the measures to prevent or eliminate the water safety hazards. According to WEDC [3] water has a profound effect on human health both as a means of reducing disease and a media through which disease causing agents may be transmitted. The impact of water on health derives principally from the consumption of water containing pathogenic organisms or toxic chemicals and the use of inadequate volumes of water that lead to poor hygiene. WSP is designed to locate points of hazardous events which refer to possible contamination or interruption of a water supply. The health risk associated with each hazard is usually assessed based on the likelihood or frequency of the health problems occurring as well as its severity or consequence of occurrence. Water quality control is critical in reducing the potential for explosive epidemic events as contaminated drinking water supply is one of the most effective methods for mass transmission of pathogens to a large population.

In the urban areas studied, we found that there are high number of cases of gastro-intestinal disease which could be attributed to the consumption of water that do not meet the standards for coliforms and E-coli when tested.

In Jalingo, we gathered from respondents that dysentery, typhoid and at times cholera cases were so high in the town in 2013 that they feared it may escalate into epidemic proportion. Owerri hospital sources indicate that typhoid disease was the most reported cases in the urban area in 2012.

The recent outbreak of cholera in some parts of Ibadan goes to show that public water supply system is dysfunctioning in many ways than one resulting in the delivery of water of poor quality to consumers. Furthermore, the city of Port Harcourt in Rivers State has been witnessing high incidence of dysentery and typhoid, which indicate that residents consume poor quality water.

The reported cases of water borne diseases from these centres are high that the figures which are always very high may not be doubted.

The poor water supply safety plan observed in Nigeria has some implications for the general urban development. Urban areas are not inhabitable when people's health is compromised as a result of the consumption of poor quality water. For example the workforce becomes weak and in some extreme situation migrate to other urban areas. This will result in low productivity as they would engage in repeated late coming and early dismissal to work, or in case of migration, lack of qualified manpower. The economic loss associated with this is bound to be high and this will negatively impact on the healthy growth of the city. WSP is very important for the sustainability of urban water supply and the need to ensure this sustainability means that the plan should adequately incorporate both human and material resources available in the urban area.

\section{Conclusion}

In this paper, we have tried to explain the meaning of water safety plan and the varying levels of its development in six selected urban areas of the six geopolitical regions of Nigeria. From the analysis, we found that out of the six urban areas, only two are faring well regarding the development and implementation of water safety plan. This is not so cheering in a country where the majority of health problems of urban residents could be confidently traced to water borne diseases that undoubtedly are as a result of the consumption of piped water of 
doubtful quality. As a result of the magnitude of the health problems associated with water borne diseases, every effort should be made to get all urban areas develop and implement water safety plan as part of their water supply policy framework for the delivery of potable water to consumers. Such plan will need to be periodically reviewed and revised so that it always addresses the water supply needs of the people and account of the experiences being observed during its implementation.

\section{References}

[1] Ezemonye, M.N. (2009) Surface and Groundwater Quality of Enugu Urban Area. Unpublished Ph.D. Thesis, University of Nigeria, Nsukka.

[2] Batram, J., Corrales, L., Davison, A., Deere, D., Drury, D., Gordon, B., Howard, G., Rinehold, A. and Stevens, M. (2009) Water safety Plan Manual: Step-by-Step Risk Management for Drinking Water Supplies. WHO, Geneva.

[3] WEDC (2013) Water Supply and Surveillance Monitoring. Loughborough University Press, UK.

[4] Smith, M. and Reed, B. (2013) An Introduction to Water Safety Plan. Fact Sheet 8 WEDC Publication.

[5] Hinkle, D.E., Wiersma, W. and Jurs, S. (1979) Applied Statistics for the Behavioural Sciences. Rand McNally College Publishing Company, Chicago. 
Scientific Research Publishing (SCIRP) is one of the largest Open Access journal publishers. It is currently publishing more than 200 open access, online, peer-reviewed journals covering a wide range of academic disciplines. SCIRP serves the worldwide academic communities and contributes to the progress and application of science with its publication.

Other selected journals from SCIRP are listed as below. Submit your manuscript to us via either submit@scirp.org or Online Submission Portal.
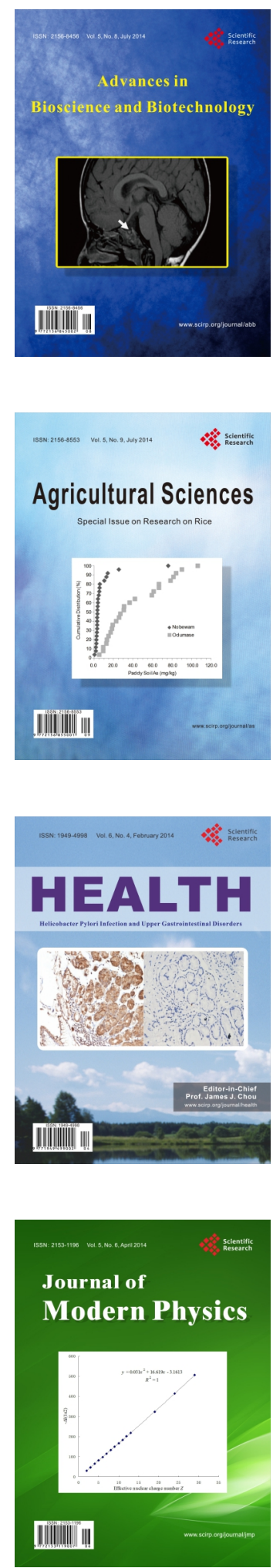
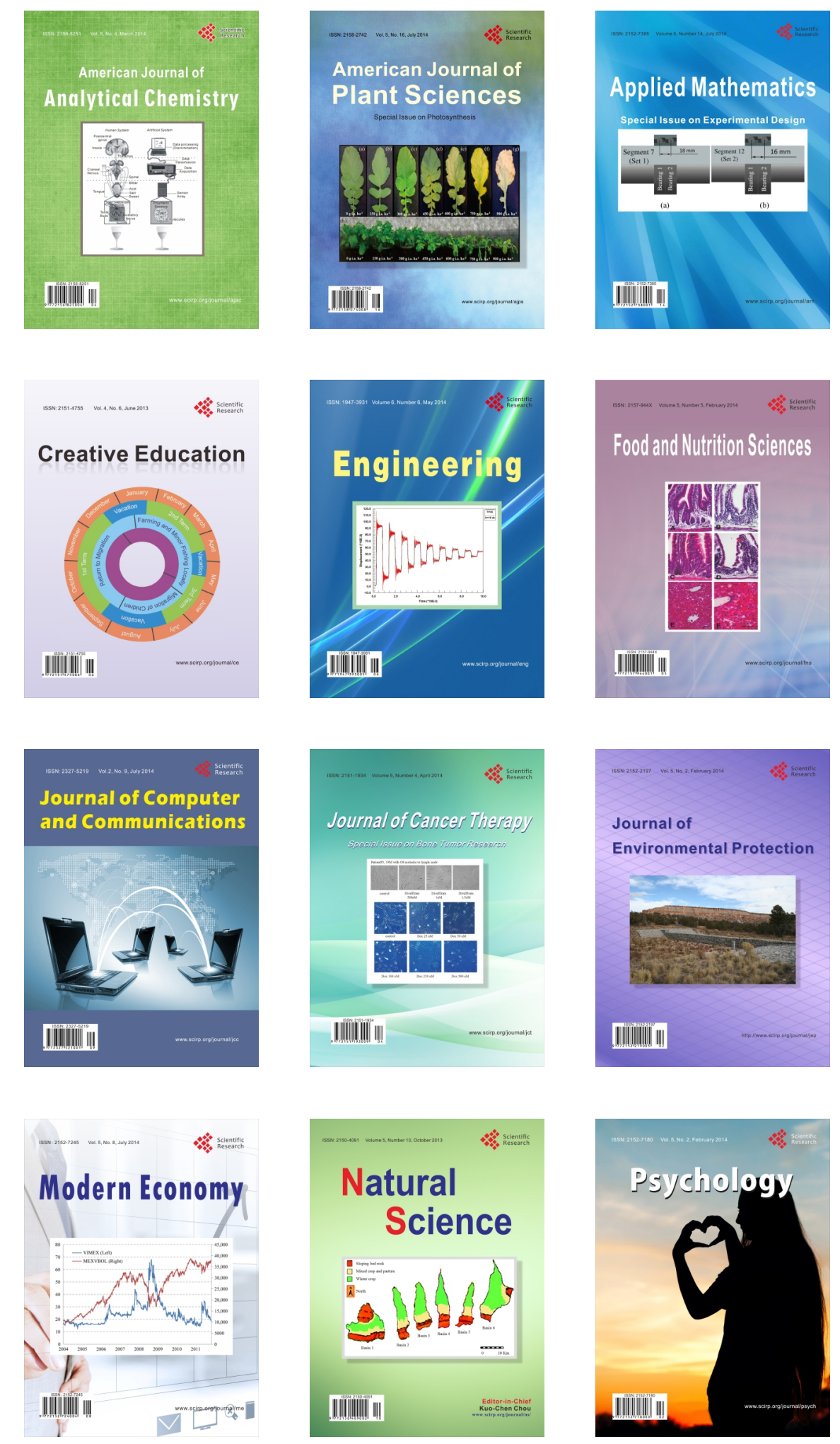